\title{
Angst og håb i kvinders forestillinger om transitionen fra arbejdsliv til pensionistliv Udforsket gennem metoden Visual Matrix
}

\author{
Anne Liveng \\ Center for Sundhedsfremmeforskning, Roskilde Universitet \\ aliveng@ruc.dk
}

Liveng, Anne (2019). 'Angst og håb i kvinders forestillinger om transitionen fra arbejdsliv til pensionistliv: Udforsket gennem metoden Visual Matrix' i Tidsskrift for Forskning i Sygdom og Samfund, nr. 30. 175-197.

Overgangen fra arbejdsliv til pensionistliv er omgivet af stærke samfundsmæssige, normative diskurser, samtidig med at den kan indeholde sociale, psykiske og sundhedsmæssige udfordringer for den enkelte. Derfor kan overgangen være vanskelig at tænke og tale om $i$ hverdagens kommunikation. I artiklen analyseres empirisk materiale skabt gennem den psykosociale metode Visual Matrix. Visual Matrix er en psykodynamisk, gruppebaseret metode, hoori deltagerne gennem forestillinger, præsentation af indre billeder og associationer omgås et emne. I artiklen analyseres en Visual Matrix med 14 kvindelige deltagere centreret omkring temaet "Forestillinger om overgangen fra arbejde til pensionistliv".

Artiklen introducerer metoden og den psykodynamiske og psykosociale metodologi bag Visual Matrix. Den viser gennem eksemplariske nedslag i den transkriberede matrix-tekst og analyser af centrale billeder kompleksiteten og det stærke følelsesmæssige indhold $i$ deltagernes forestillinger om transitionen. På baggrund heraf diskuteres, om det er muligt at rumme og bearbejde de mangfoldige psykiske udfordringer, forestillingen om transitionen 
fra arbejdsliv til livet som pensionist kan rejse, indenfor til rådighed stående forståelser og diskurser.

\section{Anxiety and hope in women's images of the transition from working life to retirement: Explored through the Visual Matrix method}

The article analyzes empirical material stemming from an explorative study of images of transitions in late life. It is based on an interdisciplinary research project, Exploring Life Transitions in Old Age through a Visual Matrix (2014-15). The project explored a) the transition from working life to retirement, $b$ ) the transition from ordinary mental function to forms of dementia, and c) the transition from life to death. Empirical material was produced through the Visual Matrix method, and a matrix was held for each theme area with different groups of invited participants. This article focuses on the transition from working life to retirement, as it emerged through 14 female matrix participants' visualizations. A Visual Matrix is a group-based, psycho-socially inspired method, which through its potentials to contain difficult and ambivalent feelings, is able to bring insights into layers of meaning, which can be difficult to express.

The article introduces the method Visual Matrix for a Danish, secondary Nordic audience. Through examples from the transcribed matrix text and analyzes of central visualizations it shows the complexity and the strong emotional content of the participants' ideas about the transition. The analysis shows that the transition holds complex ideas and feelings. Selected visualizations illustrate how the transition activates hope, anxiety and despair among the female participants. Recurrent themes are: a) fear of passivity, disease and decay versus a longing for »letting go«; b) fear of loss of individuality versus joy of belonging to a group with new, for younger persons, hidden opportunities, and c) despair associated with the end of individual life versus hope associated with continued symbolic life through future generations.

The visualizations challenge concepts of late life as possible to categorize in a $3 \mathrm{rd}$ and 4 th age, as retirement is portrayed as the entrance to old age and thus the entrance to essential aspects of both categories.

Finally, the article discuss whether it is possible to accommodate to and process the diverse psychological challenges the transition from working life to retirement contains, within available understandings and discourses. 


\section{Introduktion}

Artiklen præsenterer analyser af empirisk materiale fra en eksplorativ undersøgelse af forestillinger om transitioner i det sene liv. Den er baseret på et tværfagligt forskningsprojekt, Exploring Life Transitions i Old Age through a Visual Matrix (2014$15)^{1}$, med deltagelse af danske, norske og britiske forskere. Gennem analyser af menneskers forestillinger om transitionerne udforskede projektet a) overgangen fra arbejdsliv til pensionistliv, b) overgangen fra almindelig mental funktionsevne til former for demens og c) overgangen fra liv til død. Empirisk materiale blev produceret gennem metoden Visual Matrix, og der blev afholdt en matrix for hvert temaområde med forskellige grupper af inviterede deltagere (Liveng et al., 2017). Denne artikel fokuserer på overgangen fra arbejdsliv til livet som pensionist, sådan som den fremstod gennem 14 kvindelige matrix-deltageres forestillinger herom.

\section{Formål}

Formålet med artiklen er 1) at introducere metoden Visual Matrix for et dansk, sekundært nordisk publikum, 2) gennem eksemplariske nedslag i den transkriberede matrix-tekst og analyser af centrale visualiseringer at vise kompleksiteten og det stærke følelsesmæssige indhold i deltagernes forestillinger om transitionen, og 3) på baggrund heraf at diskutere, om det er muligt at rumme og bearbejde de mangfoldige psykiske udfordringer, forestillingen om transitionen fra arbejdsliv til livet som pensionist kan rejse indenfor til rådighedstående forståelser og diskurser.

Artiklen beskæftiger sig udelukkende med forestillinger om overgangen fra arbejdsliv til livet som pensionist. Grunden hertil er, at matrixen, der udforskede denne overgang, rummede de mest påfaldende indblik i, hvad og hvordan, her en gruppe kvinder, forstillede sig i forbindelse med overgangen. Både den visuelle matrix om overgangen fra almindelig mental funktionsevne til former for demens, og matrixen om overgangen fra liv til død havde forventeligt et særdeles tungt følelsesindhold med præsentation af indre billeder af opløsning, angst, sorg, tab og tomhed. Men også den matrix, der her er i fokus, indeholdte emotionelt stærke billeder og forestillinger, der på baggrund af fremherskende diskurser om pensionister som aktive, engagerede og selvrealiserende individer - og på baggrund af deltagernes forholdsvist privilegerede situation som veluddannede, 
økonomisk velstående og socialt anerkendte - umiddelbart kunne undre og kalde på yderligere udforskning.

\section{Baggrund}

De transitioner, vi i projektet ønskede at udforske, udgør potentielt psykosociale udfordringer, samtidig med at transitionerne er omgivet af stærke både videnskabelige, politiske og kulturelle forståelser og diskurser.

Indenfor gerontologien har særligt aktivitetsteorier kæmpet med tilbagetrækningsteorier om at vinde hegemoni (Algreen-Petersen, 2011; Katz, 2000; Kirk, 2009; Marshall, 1995). Vi lever i den vestlige verden længere end nogensinde tidligere, og det sene liv er for store dele af befolkningen præget af større sundhed og langt flere muligheder end før. Samtidig bærer ældre i høj grad sygdomsbyrden i den vestlige verden (Westendorp \& Kirkwood 2007), hvilket kan beskrives med begrebet "compression of morbidity" (Fries 2005). På baggrund af den nye, lange alderdom og den store helbredmæssige spredning hos mennesker over 65+ blev en opdeling af det sene liv i to faser lanceret. Socialhistorikeren Peter Laslett, (1989) gjorde begreberne tredje og fjerde alder velkendte i gerontologiske fagkredse. Laslett (1989) beskriver ældre mennesker, der har forladt arbejdsmarkedet på grund af pensionering, men er selvhjulpne, ressourcestærke og magter eget liv, som tilhørende tredje alder, mens ældre, der har svigtende særligt fysiske ressourcer og har brug for støtte fra andre til at magte deres hverdag, ses som tilhørende kategorien fjerde alder. Begreberne vækker opmærksomhed på, at "ældre" ikke bare er én homogen gruppe og nuancerer derved forståelsen af ældres behov.

Begreberne tredje og fjerde alder er dog også blevet kritiseret af den kritiske gerontologi. Twigg (2006) hævder, at optimistiske beskrivelser af tredje alder kun er mulige, fordi det hun benævner "dikotomien" mellem tredje og fjerde alder muliggør, at udfordringer forbundet med aldring projiceres "into a dark Fourth Age". Gilleard \& Higgs (2011) bruger det psykoanalytiske begreb "abjection" til at argumentere for, at "fjerde alder" ikke bare afspejler en fysisk og mental realitet, men også repræsenterer en kollektiv, social forestilling, hvori forestillinger om svækkelse, forfald og manglende kropslig kontrol kan placeres. Derved kan forestillinger om tredje alder "friholdes" for negative og skræmmende dimensioner af aldringsprocessen.

At aldring er genstand for diskursive kampe, viser også omsorgsforsker Hanne Marlene. Hun ser, at der på policy niveau i Danmark i 2000'erne er foregået en 
»radikalisering " af idealet om ældres selvstyring og eget ansvar i offentlige dokumenter. "Radikaliseringen" går hånd $\mathrm{i}$ hånd med en diskursiv opdeling af ældre i to adskilte grupper; de selvbestemmende og de skrøbelige (Dahl, 2011: 148). Den historiske og kulturelle kontekst er optaget af begreber om "aktiv aldring" og "rehabililitering", og den ønskværdige aldring defineres ofte ud fra grad af selvhjulpenhed (fx Hjemmehjælpskommissionen, 2013). Individuelle valg og ansvarstagen fremstilles typisk som det, der betinger "den gode alderdom" (Bakken, 2014; Dahl, 2011).

I samtiden er transitionen særligt fra arbejdsliv til pensionistliv højaktuel. Politiske debatter om hævelse af pensionsalderen ses præget af antagelser om, at alle danskere kan og vil kunne arbejde, til de er højt oppe i alderen. Initiativerne til at hæve pensionsalderen mødes af indvendinger fra for eksempel de lavest uddannedes fagforeninger (Fagbladet 3F, 2017), der påpeger, at mange af deres medlemmer ikke vil nå at få glæde af en offentlig pension, hvis pensionsalderen fastsættes til 70 år.

Pensionister som gruppe beskrives tilsvarende ofte gennem dikotomiske og stereotype diskurser (Liveng, 2016), som enten "det grå guld"; aktive, forbrugende og selvrealiserende individualister, eller modsat som "ældrebyrden"; en hastigt voksende masse, der mest er kendetegnet ved at udsuge de offentlige budgetter til skade for yngre generationer.

Subjektive bearbejdninger og betydningsdannelser i forbindelse med overgangen fra arbejde til pensionistliv foregår således i en videnskabelig, diskursiv og politisk kulturel og historisk kontekst, der er udspændt mellem en række mere eller mindre unuancerede poler. På denne baggrund fandt forskergruppen det nødvendigt at gå eksplorativt til værks og undersøge transitionen gennem en metode, der er i stand til at skabe et rum, der er trygt nok til at forskningsdeltagerne kan tale også om de dimensioner, der kan være følelsesmæssigt vanskelige at formulere sig om og som samtidigt er udgrænsede af tilgængelige diskurser (Fairclough, 1992, 2008; Hollway, 1989; Hollway \& Jefferson, 2013).

Traditionel psykosocial forskning og nyere livsalderforskning finder, at overgangen mellem livet som aktiv på arbejdsmarkedet og livet som pensionist kan rumme både tab og muligheder og kan bevirke store identitetsmæssige forandringer (Erikson \& Erikson, 1998; Fristrup \& Munksgaard, 2009). Både sociologiske og kulturhistoriske forskere lægger vægt på at transitionen i høj grad sker ind i noget ukendt. En britisk undersøgelse, inspireret af Norbert Elias' sociologiske teori, drager paralleller mellem denne overgang og ungdomsfasens overgang til voksenlivet (Goodwin \& O'Connor, 2012). Det gælder fx, at pensionister separe- 
res fra andre voksne, når det gælder aktivitetstilbud, at der er begrænset kontakt mellem pensionister og andre aldersgrupper, samt at pensionisters sociale rolle kulturelt er tvetydig og uklart defineret. Bakken (2014) hævder at pensionistlivet er ukendt for erhvervsaktive, og at det ukendte forbundet med aldring altid potentielt er skræmmende. Disse indsigter kan pege på, at der eksisterer et vidt rum for forestillinger og fantasier i forbindelse med overgangen til livet som pensionist.

\section{Metodologi}

Projektet - og denne artikel - bygger på en psykodynamisk og psykosocial metodologi. Tilgangen understreger den opfattelse, at sociale og samfundsmæssige dimensioner af en analyse hverken kan eller bør adskilles fra en traditionel psykodynamisk opmærksomhed på subjektet (Hollway, 2008; Olesen, 2013). En psykosocial tilgang trækker på psykodynamiske paradigmer om subjektivitet sammen med forståelser for sociale konstruktioner og situering af subjekter. Ifølge psykosocial tænkning kan psykodynamisk forsvar ikke reduceres til noget individuelt, men er på samme tid en indre-psykisk og en social, diskursiv og inter-subjektiv proces. Det intra-psykiske og det inter-psykiske ses som uadskilleligt og som indlejret i samfundsmæssige diskurser og forståelser.

En Visual Matrix er en psykodynamisk og psykosocialt inspireret metode, der giver mulighed for at fremkalde personlige og kollektive forestillinger, der almindeligvis udelukkes fra hverdagens bevidsthed og kommunikation. Metoden er gruppebaseret og kan med fordel anvendes i udforskning af emotionelle og affektive aspekter af et tema. Gennem visualisering, associativ tænkning og ved at rumme vanskelige følelser og tanker, kan metoden nå mangfoldige og komplekse betydningslag (Froggett, Manley, \& Roy, 2015). Den kan siges at opfordre til det, Freud benævnte primær-procestænkning fremfor til sekundær-procestænkning (Gammelgård, 1986; Freud, 1983). Metoden adskiller sig fra traditionelle fokusgruppeinterviews ved ikke at fokusere på kognitive bearbejdninger af eller diskussioner om et tema. At visualiseringerne i de tre Visual Matrix ofte indeholdte elementer af og referencer til kunst og kulturelle frembringelser kan illustrere pointen om, at her er tale om en anden måde at tænke på, end det forekommer i et fokusgruppeinterview (For yderligere indføring i metodologien se: Ramvi, E., Gripsrud, B.H., Liveng, A., Lading, Å., Froggett, L., Manley, J. and Hollway, 2018).

Opfordringen til præsentation af indre billeder og forestillinger kalder på sceniske beskrivelser. Scenisk erfaring er ifølge Lorenzer den grundlæggende form, 
vi som mennesker opfatter i:"... for Lorenzer, sensual and affective experience constitutes an autonomous register of being - the scenic - which, although always explicated in conscious spoken existence, is in some sense in excess of and radically opposed to it." (Bereswill, Morgenroth, \& Redman, 2010: p. 24).

Under matrixen fremstiller deltagerne deres visualiseringer, forestillinger og følelser i relation til det fælles tema. Målet er ikke udveksling af holdninger, og gennem rammesætning inden matrixen påbegyndes og undervejs søger facilitator at undgå og bremse egentlige diskussioner mellem deltagerne ved selv at byde ind med visualiseringer eller forestillinger. I matrixen dannes via de billeder og forestillinger, der fortælles frem, en form for sproglig "collage" eller sammensætning af scener skabt af deltagerne og indeholdende energi, der indeholdes i den enkelte visualisering og den synergi, det viser sig, der opstår imellem de fortalte visualiseringer. "Collagen" indeholder et komplekst net af betydninger, der efterfølgende kan analyseres "dybdehermeneutisk" på baggrund af en psykosocialt inspireret tolkningsramme.

Ved at belyse forestillinger om overgangen fremfor mod viden, erfaringer og holdninger, rettes opmærksomheden særligt mod den symbolske, indre og kulturelt delte verden i form af myter, billeder, ideer og deres tilknyttede følelsesindhold. Herved kan opnås indblik i bevidsthedslag, der som oftest ikke ekspliciteres i hverdagens kommunikation; enten fordi de kan være vanskelige at tale om og rumme for den enkelte og i samtalen med andre, eller fordi vi savner sprog til at udtrykke det komplekse og måske ambivalente følelsesindhold igennem.

\section{Deltagere}

Matrixen "Fra arbejdsliv til livet som pensionist" havde 15 deltagere, 14 kvinder og en mand (forskeren der faciliterede matrixen). Rekrutteringen afspejlede ikke en hensigt om repræsentation hverken uddannelsesmæssigt eller økonomisk, hvilket der naturligvis kan stilles spørgsmålstegn ved. Da afprøvningen af metoden Visual Matrix var ny for de involverede nordiske forskere, og matrixen foregik på engelsk af hensyn til de deltagende engelske forskere, var strategien $\mathrm{i}$ rekrutteringen primært at invitere deltagere, der var nysgerrige over for metoden og ville kunne gennemføre processen på engelsk. En af de danske forskere rekrutterede derfor deltagerne til denne matrix gennem sit brede faglige netværk. De fleste deltagere var ml. 50 og 65 år; hovedparten var aktive på arbejdsmarkedet, to var netop gået på pension. Alle havde videregående uddannelser og var socialt forholdsvist velstillede. 
I rekrutteringen blev der sigtet mod at invitere deltagere, der var midt i livet - ud fra den betragtning, at i denne alder er pensioneringen indenfor en overskuelig tidsmæssig rækkevidde. Der blev uden held forsøgt rekrutteret deltagere af begge køn. De 14 kvinder deltog kun i denne matrix og havde ikke noget forhåndskendskab til metoden.

\section{Visual Matrix: Forløb og proces}

En matrix indledes med stimulus materiale af relevans for undersøgelsestemaet. Matrixen om overgangen fra arbejde til pensionering begyndte med, at deltagerne tegnede deres forestillinger om overgangen på papir til eget brug. Herved stimuleres deltagernes indre billeder som en forberedelse til matrixen og en tilnærmelse til det, psykoanalytikeren Bion (1970) benævner "reverie" - en tilstand der nærmer sig dagdrømmens. På dansk vil en mere dækkende betegnelse måske være en "meditativ tilstand"; i hvert fald fortalte flere deltagere efter matrixprocessens afslutning, at de oplevede sig selv som i en meditativ form for væren under matrixen.

Deltagerne sidder herefter i en "snefnugs-formation"; en stoleopsætning, der medfører at ingen har direkte øjenkontakt med hinanden, idet stolene er placeret $i$ en forskudt cirkel. Formationen afholder deltagerne fra at tale direkte til hinanden, hvorved gruppedynamikker begrænses. Matrixen faciliteres af en deltagende forsker, hvis rolle er værtens: Med egne bidrag opfordrer hun eller han deltagerne til at bidrage med deres indre forestillinger, følelser og associationer, efterhånden som de opstår. Facilitatoren holder sig tilbage, når matrixen er i proces. Visualiseringer bringes frem, hvis og når deltageren føler behov herfor. Inspireret af begrebet om "frie associationer" (Freud, 1929) er der intet krav om at tale eller nogen rækkefølge, der skal etableres. Deltagerne bedes indledningsvis om ikke at fortolke på det sagte undervejs. I stedet opleves at billeder, følelser og associationer vokser frem som net af betydninger og danner et fælles tredje; en collage, skabt af alle. Selve den visuelle matrix optages på diktafon og transkriberes verbatim. De udvalgte citater, der analyseres herunder, er oversat af artiklens forfatter.

Den visuelle matrix følges af en post-matrix session, der fungerer som "debriefing", opsamling og første tematiseringsfase. Deltagerne inviteres her til at bidrage med deres oplevelser af at være med i matrix-processen for at sikre, at ingen forlader den alene med ubehagelige eller overraskende følelser. Dette er af etiske og menneskelige grunde centralt, idet der i processen kan fremkomme 
angstprovokerende forestillinger. Facilitator søger at tage hånd om det følelsesmæssige indhold ved at etablere containment eller "holding environment" i gruppen (Bion, 1967; Winnicott, 1971). Det sker primært ved at lade deltagerne komme til orde med deres oplevelser og anerkende disse, men også ved at bekræfte, at billeder og forestillinger, der fremkom, indeholder dimensioner, der følelsesmæssigt og eksistentielt er udfordrende for hele gruppen, således at ingen deltagere føler sig isolerede eller ladt i stikken med det vanskelige følelsesindhold.

Herefter opfordres deltagerne til at etablere den første indledende analyse af matrixen. Det kan være ved at pege på gennemgående forestillinger, fokusere på udvikling og forandring af bestemte billeder, eller ved at genkalde sig følelsesmæssige tilstande fra matrix-processen. Input fastholdes i form af mind-maps på plancher enten af facilitator eller af deltagerne i fællesskab.

\section{Analyse-proces}

Efter deltagerne har forladt post-matrix sessionen, begynder forskernes analyse af matrix-teksten. I analysen indgår både den transkriberede tekst og de foreløbige tematiseringer, der blev gennemført med deltagerne. Analysen byggede i dette tilfælde på en dybdehermeneutisk tilgang (Nielsen, 2002). I forhold til den klassiske hermeneutiks genstandsfelt tilføjes med betegnelsen dybdehermeneutik en opmærksomhed på også de ikke-bevidste og ikke-intentionelle meningsstrukturer. Lorenzer beskriver en dybdehermeneutisk kulturanalyse, hvori han antager, at subjektive psykodynamikker reproducerer sociale og kulturelle spændinger; ikke som et direkte spejlbillede af disse (Bereswill et al., 2010:27), men med et betydningsmæssigt "overskud", der kan indeholde udgrænsede horisonter og potentialer.

Analysen forløber i tre faser, der bevæger sig fra det primært deskriptive niveau til mere "underliggende" forklarende og fortolkende niveauer. I fortolkningen indgik her dels den psykosociale teoretiske ramme og dels forskergruppens viden om fremherskende diskurser og forståelser af transitionen.

Forskergruppen stiller i forløbet tre sammenhængende spørgsmål til teksten: 1) Hvad sker i teksten, hvad siges der, hvad tales der om? 2) Hvordan foregår det der sker, hvordan bliver det sagt? (fx hvordan er den emotionelle tone, hvilke retoriske strategier benyttes?) og 3) Hvorfor sker dette/hvorfor siges dette på denne specifikke måde: Hvordan kan det forklares? (med inddragelse af anden viden og teori).

Forskergruppen brugte den efterfølgende dag på 1. trin i analysen af matrixteksten. 2. trin bestod $i$, at en af forskerne (denne artikels forfatter) gennemar- 
bejdede materialet mere detaljeret: Beskrev matrixens forløb, sammenlignede og samlede billeder og beskrev deres udvikling og følelsesindhold. Nogle uger senere etablerede de involverede forskere et tolkningspanel, hvilket udgjorde 3. og sidste fase i analysearbejdet. Der blev foretaget en psykosocialt inspireret tolkning af materialet. Forståelsen af billeder, forestillinger og gennemgående temaer blev diskuteret i panelet, på baggrund af psykosocial teori (Hollway, 2008) og i relation til litteratur vedrørende transitionen.

I den følgende analyse bruges begreberne forestillinger og visualiseringer synonymt, mens billeder og scener ses som underkategorier, der beskriver helhedsprægede, sammenhængende og sanselige visualiseringer.

\section{Analysens fund og temaer}

Betragtes matrix-teksten som en helhed ses at de centrale billeder sammenvæves, udvikles og forandres undervejs. Der forekommer en bevægelse fra et stærkt emotionelt og dikotomisk indhold frem mod mere balancerede og integrerede billeder eller scener.

Karakteristisk for flowet i denne matrix var en vekslen mellem forestillinger om pensioneringen som forbundet med håb og muligheder og forestillinger forbundet med angst og tab: af helbred, status, socialt liv og betydning. Paradoksalt nok blev arbejdet og arbejdslivet, som flertallet af deltagerne stadig var involveret i, kun yderst sporadisk belyst. Når arbejdet blev nævnt, var det i abstrakte vendinger - som noget, der gav struktur på hverdagen, og hvor man vidste, hvad ens værdi bestod i, men også som noget begrænsende, rutinemæssigt og ikkekreativt. I stedet var fokus på eksistentielle spørgsmål, der havde med det sene liv og livets afslutning at gøre.

Analysen af den transkriberede matrix centrerede sig om tre gennemgående spændinger: a) frygt for passivitet og ensidig afhængighed kontra en længsel efter at "lade stå til", b) angst for tabet af individualitet og social synlighed kontra glæde over at tilhøre en gruppe med nye, for andre skjulte, muligheder for kreativitet og oplevelser, og c) fortvivlelse forbundet med det individuelle livs slutning kontra håb forbundet med de kommende generationers liv, herunder det man følte, man kunne give videre.

I det følgende ses først på to af matrixens indledende visualiseringer, der så at sige rammesætter det følgende indhold. Herefter analyseres de tre gennemgående spændinger i materialet ud fra centrale billeder, hvori de udfoldes og foran- 
dres. Samtidig gives herved et indblik i, hvordan billeder vokser frem, kobles til hverdagsnære fortællinger, og hvordan der sker en form for bearbejdning af det emotionelle indhold i billederne under matrixen. Valget af at lade analysen tage udgangspunkt i visualiseringer frem for i temaer skyldes en hensigt om at vise den "sceniske form", hvori der tales i en Visual Matrix. Samtidig fastholdes herved antagelsen om, at kognitivt og emotionelt indhold er uadskillelige dele af et hele, og det tilstræbes at vise, hvordan dette hele ikke bare udspringer af individuelle forestillinger, men også skabes og udvikles i det kollektive rum, matrixen udgør.

\section{Lågen til grøn eng eller mørk nat}

Centralt var det, at pensioneringen for deltagerne repræsenterede tærsklen til det sene liv. Overgangen fra arbejdslivet til livet som pensionist markerede selve indgangen til alderdommen - forstået som indgangen til den på en gang aktive, frie og velfungerende "tredje alder" og samtidig indeholdende "fjerde alders" forfald. Forestillinger om pensioneringen blev således udtrykt som på den ene side en åbning til et nyt liv, og på den anden side et forstadie til døden.

En deltager fremstiller ud fra sin tegning en af de første visualiseringer i matrixen:

"Det billede jeg tegnede forestillede en låge ind til en eng. Og på engen, i engen, er der en masse meget klare farver og det er et meget lykkeligt sted at være. Og det jeg kom frem var en steril boks, så min overgang er faktisk mod farver og lys, og en følelse af... den der dansende bevægelse som en af de andre beskrev, en mulighed for at være mere mig selv. "

Ser vi på, hvad og hvordan transitionen beskrives i dette billede, er det tydeligt, at der etableres en stærk modsætning mellem et før: "en steril boks", der betegner talerens følelsesmæssige opfattelse af arbejdslivet - til et fremtidsscenarie; Pensionistlivet, der indeholder glæde, bevægelse og sanselighed. Disse kvaliteter kobles til en vision om selvrealisering "...en mulighed for at være mere mig selv."

Den entydigt positive forestilling om overgangen får dog i matrixen ikke lov at stå uimodsagt; straks derefter opstår modbilledet til den idylliske fremstilling af pensionistlivet $\mathrm{i}$ form af en anden deltagers henvisning til en digtstrofe af Dylan Thomas: "Gå ikke roligt ind i den mørke nat." Digtet beskriver alderdommen som en mørk nat, som den aldrende for enhver pris må kæmpe imod. Den metaforiske fremstilling i digtet af alderdommen som en mørk nat afløser billedet af pensio- 
nistlivet som en dans på grønne enge - med et på én gang negativt følelsesindhold og højt affektivt indhold - du må kæmpe mod den mørke nat, ikke bare "roligt" acceptere. Forestillingen om pensionistlivet får modsatte konnotationer; det er ikke forbundet med selvrealisering, men snarere med tomhed og død.

Både lågen, den grønne eng og den mørke nat kan siges at være kulturelle symboler, der her anvendes forholdsvist traditionelt. En fortolkning kan pege på, hvordan en dikotomisk tænkning om det sene liv, der er udpræget i vores samtid, reproduceres i disse indledende visualiseringer; Det er enten eller - idyl eller død. Mest interessant er måske spørgsmålet om, hvorfor betydninger af arbejdet ikke fremstilles. Hvorfor indeholder visualiseringerne hverken indholds- eller følelsesmæssige billeder af tab i forbindelse med opgivelsen af arbejdet? Forskergruppen tolkede dette som et udtryk for, i hvor høj grad det var det kommende, ukendte, der optog matrix-deltagerne. Det ukendte som pensionistlivet repræsenterer tiltrak sig den psykiske energi og genererede billeder med stærkt affektivt indhold, fordi det var fremmed og dermed skræmmende for deltagerne, og fordi det var forbundet med angsten for livets afslutning, som metaforen "den mørke nat" antyder.

\section{Den dybe lænestol}

Billedet af den dybe lænestol fremkommer tidligt i matrixen og vender tilbage i forskellige udformninger, men med modsatrettede konnotationer. Indledningsvis repræsenterer den dybe lænestol en angstfyldt forestilling om opslugning, passivitet og afmægtighed:

"Jeg forestiller mig, at jeg sidder i en stor brun lænestol. Stor, stor, stor pude og jeg er lige ved at drukne i den. Der er jeg. Sidder. Jeg tænker, at denne overgang handler om at blive gammel og $i$ disse dage er jeg meget bange for, at jeg vil miste min forstand. At jeg vil blive opslugt af ... uh. Alzheimers eller demens eller hvad det hedder. Fordi nogle af mine venner kan ikke, er i den situation. Og jeg synes det er så skræmmende og uhyggeligt. Så jeg har en masse tanker om det. Er dette, hoad det er at øh, nu er vi lukket ude af samfundet, ude af livet."

Lænestolen repræsenterer frygten for tilstande af væren, der nærmer sig døden: at forsvinde ud af det sociale fællesskab, miste forstand, kontrol og individualitet. At drukne i lænestolen beskriver en frygt for at blive fanget af kræfter uden for ens 
kontrol. Som demensen frygtes at sluge hjernen, sluger lænestolen i billedet den talendes krop, vilje og handlekraft.

Den dybe, brune og bløde lænestol associeres senere med besøg hos bedsteforældre. I denne association forekommer en scenisk beskrivelse af besøg hos et par bedsteforældre, hvor bedstefar har fået amputeret begge ben og altid ligger på en sofa. Lænestolen refererer her på den ene side til hygge, ro og tryghed: at sidde tæt på bedstemors bløde krop, få læst historier; og på den anden side refererer den til passivitet og stilstand. Det sidste scenen frembringer, er minder om et tikkende ur, den syge bedstefar, der ligger på sofaen, samtidig med at bedstemor skildres med forklæde og gryder der simrer; evigt i gang med at lave mad.

Scenen indeholder en tydelig kropslighed, idet både bedstefars og bedstemors kroppe beskrives sanseligt som hhv. beroligende og skræmmende eller frastødende. I senere associationer gentages og forstærkes den kropslige dimension af visualiseringerne gennem forestillinger om bedstemødres og mødres kroppe, som fremstilles som på en gang uformelige og kvælende, men samtidig nærende og beroligende. Kroppen som noget der kan kvæle og blive kvalt gentages i en visualisering af massagestole i en lufthavn. Stolene indeholder her både en sikkerhedsskabende og en afmægtiggørende dimension: Noget sker med kroppen, men du er ikke i stand til selv at bevæge den.

Visualiseringer forbundet med lænestole (sofaer, massagestole) er således skræmmende, men repræsenterer også hvile og ro. De ambivalente følelser, som forestillingen om transitionen fra arbejdsliv til pensionisttilværelse kan vække, er tydelige i billedet og i dets udvikling. Lænestolen symboliserer en individualiserings-proces, der drejes tilbage; en bevægelse tilbage til en dyb og ensidig afhængighed af omgivelserne. Afhængigheden forbindes med barndommens fysiske afhængighed af moderen. De angstfyldte dimensioner af transitionen hænger, som de udtrykkes i billedet, sammen med frygten dels for passivitet, afhængighed og afmagt, dels for at miste adgang til socialt liv og betydning. Via referencen til bedstefar tangeres frygten for handicap og sygdom: Han er bogstavelig talt ude af stand til at flytte sig selv.

Visualiseringen indebærer at være låst fast, at blive lukket ude fra aktiviteter, handlemuligheder og selvstændighed - og dermed forsvinde som subjekt. Samtidig antydes i billederne en længsel efter denne opgivelse; en overgivelse til en tilstand af passiv væren, som reflekteres gennem erindringen om tryghed.

I senere, mere hverdagstætte, passager fremstilles ligeledes en tilfredshed med at have tid og være i ro; her som en kontrast til arbejdslivets hektiske aktivitet: 
"Min yngste datter ringer ofte til mig om morgenen, når hun er på vej til arbejde på sin cykel, og hun siger 'åh, sidder du der med din kaffe og din avis?' Og det gør jeg, og jeg husker, nå ja, jeg har tiden, og det er dejligt med kaffen. Du er ikke nødt til at skynde dig ud ad døren, som du har været nødt til i mange, mange år.

Det er godt."

Ambivalensen er stadig tydelig også i dette citat; taleren må minde sig selv om, at hun skal huske, at det er dejligt at have tid nok. Tankevækkende er det, at billedet af den dybe lænestol, efterhånden som det gennem matrix processen overgår til at være en skildring af en hverdagssituation, mister sin stærke, angstfyldte karakter. Iagttagelsen kan dels understrege betydningen af matrixens opfordring til at tale i billeder og forestillinger. De umiddelbare visualiseringer når andre følelsesmæssige og symbolske bevidsthedslag end fortællinger fra dagligdagen, og er på denne måde i stand til at fremstille dimensioner af transitionen, der ellers kan være vanskelige at forholde sig til. Dels kan udviklingen i billedet pege på, at der sker en bearbejdning af følelsesindholdet undervejs i matrixen; det bliver lettere at forholde sig reflekteret til billedet.

Fortolkningen - spørgsmålet om hvorfor - pensionistlivet fremstilles, som det gør i visualiseringen af lænestolen, kan besvares ud fra de følgende scener og hverdagsfortællingen: For matrix-deltagerne indebærer pensionistlivet angstprovokerende forestillinger om ikke bare social isolation og ensomhed, men også om sygdom, forfald og alvorlige handicap. Fremstillingerne af kroppen som noget, der svigter ens vilje, som frastødende og begrænsende, er interessante, i den udstrækning de peger på og reproducerer en kulturel modstillelse af sind/vilje og materie/krop. Modstillelsen er klassisk i vestlig kultur, men i scenen, der beskriver besøg hos bedsteforældrene, nuanceres den af erindringen om roen og trygheden forbundet med bedstemors krop. I billedet af massagestolene nuanceres den af den længsel, der også indeholdes i billedet, af at noget udefra kommende bevæger en (ens krop). Her opstår et ubevidst scenisk indhold, der netop kan være svært ellers at udtrykke i en kultur, der i høj grad opfatter livet som et selvstyret projekt og vægtlægger vilje og handlen.

\section{De grå hjelmes hær}

Billedet, De grå hjelmes hær, afspejler en kompleks forestilling om ældre som på en gang stærke - som en hær - men samtidig identitetsløse. Det ovenfor refererede billede af bedstemor viste en kvinde med store bryster og mave, altid i gang med 
madlavning - på en gang skræmmende og tryghedsskabende. Bedstemoderen fremstår som et individ, som fortælleren dog ikke ønsker at ligne, hvorimod de øvrige forestillinger om ældre kvinder præsenterer dem som en (grå) masse.

De grå hjelmes hær blev brugt som en metafor for ældre kvinder, som i deres higen efter at skjule deres aldrende krop gjorde sig latterlige i omgivelsernes øjne. Samtidig fremkom blandt deltagerne i matrixen en vredesfyldt bevidsthed om selv at tilhøre denne gruppe:

\begin{abstract}
"Hver gang jeg ser en gruppe som denne, når jeg er på et museum eller vandrer $i$ bjergene, føler jeg mig frustreret, og jeg føler det som om, alle disse kvinder med gråt hår eller med farvet hår og alle deres tørklæder rundt om halsen og deres briller, røde briller, du ved, for ikke at se for gammel ud, jeg synes, det er synd for dem, og jeg tænker, jeg vil aldrig være ligesom dem! Og nu er jeg her."
\end{abstract}

Hvor billedet af lænestolen i sit udgangspunkt udtrykte frygt for et forestillet tab af kontrol over krop og sind, indeholdt visualiseringen af ældre kvinder som en grå hær en høj grad af affekt og var forbundet med vrede - både mod kvinderne set udefra som gruppe og mod en selv som tilhørende denne gruppe. På en gang foregik en andetgørelse af ældre kvinder og en subjektiv identifikation med gruppen.

Visualiseringerne cirklede som spørgsmålet om identitet. Hvem blev man som ældre kvinde? Hvordan kunne man fortsat blive genkendt som et unikt subjekt? Var man stadig genkendelig som sexuelt væsen? Vreden over at se sig selv som tilhørende denne forestillede ens masse fremstod som afmægtig: Forsøg på at skille sig ud var mislykkede, fordi alle "de andre" gjorde det samme. Det paranoid-skizoide forsvar (Klein, 1975) som billedet lægger op til - de ens, latterlige kvinder, er "de andre" - bryder sammen, da det erkendes af taleren, at hun er som dem. En mere integreret position (en depressiv position i kleinianske termer) opstår dog ikke.

Selvom billederne af bedstemødre kunne have positivt følelsesindhold, blev hverken de eller mødre fremstillet som identifikations-modeller. Som i ovennævnte citat indeholder forestillingerne primært et ønske om ikke at komme til at tilhøre gruppen "ældre kvinder".

Samtidig påpegede efterfølgende visualiseringer, at der lå skjulte muligheder i at tilhøre de grå hjelmes hær. Centralt var her forestillingen om de mange kulturelle oplevelser, gruppen havde adgang til - som andre, yngre mennesker enten ikke havde opdaget eller ikke havde tid til at nyde. Stadig er der i denne visualise- 
ring tale om, at ældre fremstilles som en masse, der som gruppe har andre muligheder end unge som gruppe:

\begin{abstract}
"Jeg har en forestilling om et hav af mennesker med grå hjelme der sidder i stole i Manchesters flotte Bridge Water hal, hoor de spiller den mest spændende, vidunderlige musik. Og yngre mennesker ved overhovedet ikke, hoad det er. Der er elektrisk! Men det er faktisk de grå hjelmes hær i deres stole, der i hemmelighed har en spændende oplevelse."
\end{abstract}

Ligesom i modstillingen af billedet af pensioneringen som en eng og en mørk nat fremstår følelsesindholdet i dette billede som et positivt modbillede til det foregående. Ældre lever i denne visualisering et hemmeligt, fantastisk liv. Således opstår der gennem billedet af de grå hjelmes hær heller ingen integration af truende og styrkende aspekter ved overgangen til pensionistlivet.

Som i foregående billede peger matrixen selv mod en fortolkning. En enkelt direkte meningstilkendegivelse hævdede, at et ungdommeligt udseende var ensbetydende med at blive elsket. Forbindelsen, der herved etableres mellem kærlighed og ungdom, kan forklare den store optagethed af kvinders forsøg på at sløre deres alder ved at "arbejde på" deres udseende. På en gang peger matrixen på angst, der er forbundet med ikke at blive elsket, og på en skam over at være "en af dem", der er nødt til dette.

Man kan tilføje, at den usynlighed som både det negative og det positive billede af de grå hjelme som masse indeholder, ligger i forlængelse af den frygt for social isolation, der også berøres i andre visualiseringer. Det er eksistentielt angstprovokerende ikke at blive genkendt som individ; usynliggørelse medfører en krænkelse af subjektet. Særligt ældre kvinder usynliggøres ofte i vores ungdomsdyrkende kultur - og forventes tilsvarende at gøre mere end mænd for at skjule aldringstegn. Billederne berører således angsten for en eksistentiel isolation - ud over den sociale.

\title{
Lommetørklæde træet
}

Et tilbagevendende billede beskrev et gammelt træ. I sin mest kondenserede form bestod denne visualisering i en udfoldet scenisk beskrivelse af et lommetørklæde træ. Det dukkede op mod slutningen af matrixen og syntes at integrere mange af de allerede præsenterede billeder og associationer. Billedet af et træ fremstod i hele otte versioner: En tyk eg, med tunge grene, ingen blade, men en enkelt rød 
frugt. Et æbletræ hvor frugtens sødme afhænger af naturens kræfter, ikke af menneskelig vilje. Kundskabens træ, der associeres til tab af uskyld forbundet med arbejdslivet, over for pensioneringen, der ses en mulighed for at vinde uskyldighed og spontanitet tilbage. Et gammelt træ, der er råddent i midten, men stadig vokser. Et egetræ plantet af Kong Christian den 4. Udseendet er formet af vestenvinden, det er mystisk. Et bonsai træ, der vokser langsomt og beskæres med neglesakse. Et fyrretræ plantet af en bedstefar, træet er deformeret af vinden. Lommetørklædetræet beskrives som følger:

"Jeg har en søster, hun er ti år yngre end jeg. Da hun blev 55 i december, prøvede jeg at dyrke et lommetørklæde træ. Det tager et til to år før du kan se en lille grøn top. Det tager ti år for det er et træ. Så gav jeg det til hende og sagde, at jeg glæder mig til at se hendes have, når jeg bliver 75. Så kan vi nyde lommetørklæde træet, og med det vil jeg gerne sige: Jeg husker, da jeg var barn og jeg elskede at ligge $i$ græsset og se vasketøjet, det rene vasketøj. Der blæste i vinden."

Den sceniske beskrivelse viser her et træ, der vokser samtidig med at først den ældste, derefter den yngre søster gennemlever overgangen fra arbejdsliv til pensionering. Som en gave bekræfter og forstærker træet forholdet mellem de to søstre, og som en fødselsdagsgave forbinder det fødsel og barndom med søstrenes nuværende alder. Med sin langsomme spiring giver træet løfte om frugtbarhed. Det peger frem mod søstrenes potentielle fremtid; forventningen om at kunne nyde dette træ selv som gamle kvinder, når de sidder sammen i haven. Symbolsk kommunikerer gaven både omsorg og kærlighed, og et ønske fra den ældste søsters side om at være i live og kunne være sammen med den yngre i alderdommen, ligesom de var det i barndommen. Som gennem en foldning af tid trækker træet en sanselig barndomserindring, der i sig selv er et billede på harmoni, ind i visualiseringen: Forestillingen om at ligge i græsset, og se på det rene vasketøj, mens vinden berører tøj og krop. Fra en tilstand af gøren eller handling (at opdyrke træet, forære det væk, der repræsenterer en nuværende tilstand) ændrer billedet sig til at repræsentere en tilstand af væren (at ligge, at se, at nyde), hvor der findes en glæde i nuet. Billedet afspejler en længsel efter uskyld, der berøres i de tidligere visualiseringer af træer. Det indeholder en længsel efter ro og hengivenhed til omgivelserne, men uden den skræmmende følelse af passivitet, som findes i billedet af lænestolen.

Alle billeder af træer, der fremstilles i matrixen, repræsenterer kontinuitet. Det enkelte individs liv er begrænset, mens visualiseringerne af træer beskriver liv som noget cyklisk, der overskrider denne individuelle begrænsning. Træerne bli- 
ver metaforer for bånd mellem generationerne, en langsom vækst, dannet af kræfter uden for menneskelig kontrol. De træer, der fortælles frem, overlever stædigt trods modgang i form af vind og vejr - og menneskers sakse. Træernes symbolske betydning ligger i forlængelse af figurer i en nordisk kulturkreds. I nordisk mytologi repræsenteres livet gennem træet Yggdrasil, og fra kristen mytologi er vi bekendt med Kundskabens træ. I matrixen præsenteres træet som en skabning, der har sin egen bestemmelse, men som til stadighed formes af det omgivende miljø. Træet som billede integrerer en sorg over livets endeligt gennem de gentagne henvisninger til forfald (kun én enkelt frugt, råddenskab) med en tillid til ny vækst. Træet konfronterer os med det individuelle livs endelighed, samtidig med at det tilbyder trøst gennem naturlig fornyelse og forlængelse, som er knyttet til generationsskiftets kontinuitet. Billedernes harmoniske karakter afspejler en integreret i kleinianske termer depressiv, måde at nærme sig aldring på; En accept af såvel begrænsningen af det personlige liv som den sorg dette indebærer, samtidig med tillid og håb knyttet til at livet fortsætter ud over det enkelte individuelle liv.

Sammenlignet med de øvrige forestillinger adskiller denne scene sig netop ved sin integration af erkendelsen af endelighed og håb om fortsættelse. I et udpræget sekulært samfund som det danske er det ikke overraskende at håbet om forsættelse ud over det individuelle liv ikke indebærer religiøse, kristne forestillinger. Den fortrøstning ved den inter-generationelle dimension, som scenen indeholder, kan dog i relation til dominerende samfundsmæssige diskurser ses som overraskende. Den overskrider i modsætning til matrixens øvrige billeder samtidens stærke fokus på individet og individets personlige selvrealisering. En forsigtig fortolkning kunne foreslå et dybtliggende behov for en meningsfuldhed, der rækker ud over det individuelle liv - et behov, der vanskeligt opfyldes i gængse diskurser om pensionistliv, aldring og alderdom.

\section{Opsamling}

Artiklen har 1) introduceret metoden Visual Matrix og dele af metodologien bag denne, 2) den har gennem analyser af centrale visualiseringer i form af billeder eller sceniske beskrivelser vist ambivalenser, kompleksitet og følelsesmæssigt modsatrettet indhold i deltagernes forestillinger om transitionen fra arbejdsliv til pensionistliv, og 3) fortolkningerne af visualiseringerne har peget på dimensioner af forestillingerne om transitionen, der falder udenfor eller adskiller sig fra 
de forståelser, diskurser og begreber, der er kulturelt er fremherskende omkring pensionistlivet.

I relation til artiklens andet formål forekom det overraskende at arbejdslivet fyldte så lidt som det gjorde i forestillingerne. Forestillingerne om transitionen fra arbejdsliv til pensionistliv skildrer den som en overgang, der medfører psykiske, identitetsmæssige og eksistentielle udfordringer. Centralt står spørgsmål om kontrol, individualitet, social inklusion og kropslighed. Forestillingerne veksler mellem polariserede billeder og integrerede. Som den ene, og skræmmende pol, ses visualiseringer, der indeholder frygt for svækkelse og begrænsninger som følge af alder: angst for begrænset social kontakt, angst for tab af individualitet og tiltrækningskraft, frygt for kropsligt forfald og for pga. af sygdom og handicap at miste selvkontrol og at havne i passivitet og ensidige afhængighedsforhold. Som den anden, positive pol, ses forestillinger, der indebærer nye muligheder og en mere harmonisk livsform, med frihed fra arbejdets disciplin, tid og ro til at følge sit eget tempo, og mulighed for selvrealisering. De polariserede billeder kan siges at afspejle samtidige opsplittede diskurser om ældre mennesker.

Billederne forholder sig indirekte kritisk til begreber om 3. og 4. alder, idet både muligheder og forfald er indeholdt på samme tid i flere billeder. Overgangen til pensionistlivet repræsenterer en indgang til begge tilstande, hvilket dermed øger dens urovækkende karakter. Herved modsiger matrixens indhold enkelt formulerede idéer, om hvad det betyder at blive pensioneret. I et Lorenzer-perspektiv kan flere af matrixens visualiseringer ses som sceniske, og som indeholdende betydningslag, der netop ikke kan favnes indenfor de kulturelt og historisk dominerende forståelser og diskurser. Det gælder for den modpol, der kan fremanalyseres til angsten for passivitet og afhængighed, en ambivalent længsel mod en selvopgivelse i nærhed til et andet menneske og det gælder for kropsligheden, der overvejende fremstilles som skræmmende, men som også kan indebærer tryghed og ro. Optagetheden af kvindekroppen og kvinders arbejde med den aldrende krop, afspejler selvfølgelig, at deltagergruppen overvejende bestod af kvinder. Men den bliver også en vigtig kommentar til tidens ungdoms- og skønhedsdyrkelse og den kan åbne for en forståelse af særligt de psykologiske udfordringer ældre kvinder kan møde i samtiden. Særligt interessant i konteksten af et moderne, sekulært samfund er de billeder, der fremstiller relationer og symbolske bånd mellem generationerne. Disse visualiseringer adskiller sig fra fremherskende kulturelle idealer om individets selvberoenhed. Forestillingen om livets fortsættelse i og gennem andre, gennem det man symbolsk set har "plantet", integrerer det indivi- 
duelle livs endeligt med en stadig fortsættelse og peger dermed ud over samtidige forståelser af livet som et individuelt projekt.

Det rige, følelsesmæssigt nuancerede materiale viser metodens potentialer for at skabe et rum, hvor både frygt, angst og håb kan fremstilles. Forløbet i matrixen sandsynliggør, at der sker en bearbejdning af det stærke følelsesindhold undervejs, og at det tilsyneladende for deltagerne efterhånden bliver nemmere at integrere adskilte positioner. Samtidig peger metoden via sit fokus på frembringelse af forestillinger på, at alle - også mennesker fra lidt yngre generationer, har indre billeder af, hvad det vil sige at blive ældre. På baggrund af matrixen kan man rejse spørgsmålet, om der eksisterer de nødvendige sociale sammenhænge et dækkende sprog for, at vi som (mid-) aldrende kan bearbejde de forestillinger transitioner i de sene liv kan indebære.

\section{Perspektivering}

Den psykosociale metodologi er forholdsvis ukendt i en dansk kontekst. Som analysen forhåbentligt har illustreret, kan den både supplere og videreudvikle indsigter, som opnås gennem kulturhistoriske, antropologiske metodologier. Samtidig trækkes der i fortolkningerne på indsigter genereret via disse metodologier.

Den norske aldringsforsker Runar Bakken præsenterer i Frygten for alderdommen (2014) en kulturhistorisk analyse, der har ligheder med flere af de pointer, der er fremanalyseret ud fra matrixen. Bakken hævder at frygten for alderdommen er forbundet med frygten for at blive ekskluderet fra samfundet og sultet/slået ihjel, sådan som det har foregået i visse før-moderne samfund. Gamle mennesker bliver "andet-gjort", fordi de yngre frygter at identificere sig med den skrøbelighed og udsathed, gamle repræsenterer. I matrixen fremgår en frygt for eksklusion/ isolation tydeligt, i en deltagers formulering om at blive "lukket ude af samfundet, ude af livet", når hun bliver ældre. Frygten fremstår her som både en eksistentiel frygt, forbundet med forfald og livets slutning og som en frygt for social isolation. Alderdommen som en andet-gørelse afspejles ligeledes i forestillingen om de grå hjelmes hær. Den kan dog samtidig ses som udtryk for det, Bakken benævner "forestillingen om den gode alderdom". Ældre er her stadig andet-gjort, men andet-gørelsen er forbundet med en stærk idealisering.

Centralt hos Bakken står antropologiske teorier om overgange som potentielt farlige, idet de indebærer opløsning af grænser og etableret orden: "Kroppens aldring innebærer en gradvis rejse tilbage til det grenseløse." (2014:28). Angsten for den 
kropslige grænseløshed genfindes i flere af matrixens visualiseringer - særligt i billedet af den tykke bedstemor og bedstefaren, der har fået amputeret begge ben. Her ses kroppe der hhv. "flyder ud over grænser", og hvis grænser er ødelagt og reducerede. Matrixen viser, at denne angst lever side om side med sin modsætning; trangen til at give sig hen, lade stå til, som det ses gennem billedet af en krop, der masseres i lufthavnens massagestol.

Bakken skriver: "For at noe skal oppleves som meningsfylt, må vi kunne se oss selv, ikke bare i fortid, og nåtid, men også fremtid. Den fremtiden finnes ikke lenger, bortset fra for noen i troen på paradiset." (2014:205). Der etableres mod slutningen af matrixforløbet en meningsfuldhed via de holistiske visualiseringer af organisk, cyklisk vækst. Matrixen viser herved et alternativ til religiøse forestillinger om paradis. Dens metodologi åbner for indsigter i spændinger og psykosociale udfordringer, men også for nye betydningslag, der almindeligvis er udgrænset af forståelser af og diskurser om aldring.

\section{Referencer}

Algreen-Petersen, E. (2011). Kan man flytte solen? Roskilde: Institut for Miljø, Samfund og Rumlig Forandring, Roskilde Universitet.

Bakken, R. (2014). Frykten for alderdommen. Om å eldes og leve som gammel (1.). Oslo: Res Publica.

Bereswill, M., Morgenroth, C., \& Redman, P. (2010). Alfred Lorenzer and the depth-hermeneutic method. Psychoanalysis, Culture \& Society, 15 (3), 221-250. https://doi.org/10.1057/ pcs.2010.12

Bion, W. R. (1967). Second thoughts. London \& New York: Karnac.

Bion, W. R. (1970). Attention and interpretation. London: Routledge.

Dahl, H. M. (2011). Who can be against Quality? In M. Ceci, C, Björnsdóttir, K \& Purkis (Ed.), Perspectives on Care at home for Older People (pp. 139-157). London: Routledge Studies in Health and Social Welfare.

Erikson, E. H., \& Erikson, J. M. (1998). The life cycle completed: Extended Version. New York: W. W. Norton.

Fagbladet, 3F. (2017). Markant befolkningsflertal siger nej til senere pension. Fagbladet 3F. Retrieved from https://fagbladet3f.dk/node/45907

Fairclough, N. (1992). Discourse and social change. Polity Press. Retrieved from http://rub.ruc. $\mathrm{dk} / \mathrm{soeg} / \mathrm{kviksoeg} /$ ?query $=0745606741$

Fairclough, N. (2008). Kritisk diskursanalyse. Hans Reitzel. Retrieved from http://rub.ruc.dk/ soeg/kviksoeg/?query=9788741251653

Freud, S. (1929). Civilization and Its Discontents. London: Penguin.

Fristrup, T., \& Munksgaard, M. E. (2009). Alderdommen er ikke, hvad den har været. In S. Glasdam, B. Appel Esbensen, \& K. Andersen-Ranberg (Eds.), Gerontologi: Livet som ældre $i$ det moderne samfund. (1., pp. 76-91). København K: Nyt Nordisk Forlag Arnold Busck. 
Froggett, L., Manley, J., \& Roy, A. (2015). The Visual Matrix Method: Imagery and Affect in a Group-Based Research Setting. Forum Qualitative Sozialforschung / Forum: Qualitative Social Research, [S.L.], v. 16,(n. 3, july, ISSN 1438-5627.), 34 pages.

Gammelgård, J. (1986). Freuds Psykoanalyse. Psykologi, en indføring i teori og anvendelse. (Hans Reitzels forlag A/S, Ed.). Købehavn.

Goodwin, J., \& O'Connor, H. (2012). Notions of fantasy and reality in the adjustment to retirement. Ageing and Society, 34(04), 569-589. https://doi.org/10.1017/S0144686X12001122

Hjemmehjælpskommissionen, S. (2013). Fremtidens hjemmehjælp - ældres ressourcer i centrum for en sammenhængende indsats. København K.

Hollway, W. (1989). Subjectivity and method in psychology: Gender, meaning and science. London: SAGE Publications, Inc.

Hollway, W. (2008). The importance of relational thinking in the practice of psycho-social research: ontology, epistemology, methodology and ethics. In H. eds. Clarke, Simon Hoggett, Paul and Hahn (Ed.), Object relations and social relations: The implications of the relational turn in psychoanalysis. Exploring Psyco-Social Studies (1., pp. 137-162). London: Ka. Retrieved from search.ebscohost.com/login.aspx?direct=true\&db=psyh\&AN=200810888-007\&site=ehost-live

Hollway, W., \& Jefferson, T. (2013). Doing Qualitative Research Differently: Free Association, Narrative and the Interview Method. (2nd ed.). London: Sage. https://doi. org/10.4135/9781526402233

Katz, S. (2000). Busy Bodies: Activity, aging, and the management of everyday life. Journal of Aging Studies. https://doi.org/10.1016/S0890-4065(00)80008-0

Kirk, H. (2009). Synet på aldring og ældre - historisk set. In S. Glasdam \& B. A. Esbensen (Eds.), Gerontologi - livet som ældre i det moderne samfund (1st ed., pp. 38-46). Købehavn: Dansk Sygeplejeråd, Nyt Nordisk Forlag Arnold Busck.

Klein, M. (1975). Envy and gratitude and other works 1946-1963. Hogarth. Retrieved from http://rub.ruc.dk/soeg/kviksoeg/?query=0701204095

Laslett, P. (1989). A fresh map of life. The Emergence of the Third Age. London: Weidenfeld and Nicolson.

Liveng, A. (2016). Aktiv aldring - en sundhedsskabende eller usynliggørende diskurs. In S. Lehn-Christiansen, A. Liveng, B. Dybbroe, M. Holen, N. Thualagant, I. C. Aaman, \& N. Birgitta (Eds.), Ulighed i sundhed - Nye humanistiske og samfundsvidenskabelige perspektiver (1., pp. 147-174). Frederiksberg C.: Frydenlund Academic.

Liveng, A., Ramvi, E., Froggett, L., Manley, J., Hollway, W., Lading, A., \& Gripsrud, B. H. (2017). Imagining transitions in old age through the visual matrix method: thinking about what is hard to bear. Journal of Social Work Practice, 31 (2). https://doi.org/10.1080/0 2650533.2017.1305342

Marshall, V. W. (1995). Social Models of Aging. Canadian Journal on Aging / La Revue Canadienne Du Vieillissement. https://doi.org/10.1017/S071498080001045X

Nielsen, B. S. (2002). Dybdehermeneutik. In O. A. (red. . Olsen (Ed.), Psykodynamisk leksikon ((1. udg., pp. 189-192). Købehavn: Gyldendal.

Olesen, H. S. (2013). The societal nature of subjectivity: An interdisciplinary methodological challenge. Historical Social Research, 38(2).

Ramvi, E., Gripsrud, B.H., Liveng, A., Lading, Å., Froggett, L., Manley, J. and Hollway, W. (2018). The Visual Matrix method in a study og death and dying: Methodological reflec- 
tions. Psychoanalysis, Culture E Society, online acc, 1-22. https://doi.org/10.1057/s41282018-0095-y

Sigmund, F. (1983). Psykoanalyse. Nye forelæsninger til indføring i psykoanalysen. (H. R. Forlag, Ed.). Købehavn.

Winnicott, D. W. (1971). Playing and reality. London \& New York: Routledge. 